for them ?" The last question aids in determining the sevority of the case.

The attempt should next be made to produce pain by active and passive morement, the patient's appearance being noted the while.

'Then ask: (18) "Is the pain sharp or dull?" If he has had rubbing or massage, ask: (19) "Is massage painful?" (20) "Does it do you good?" Proceed to inquire ab rut stiffness by asking, (21) "Does rest make the stiffness greater or less?" (22) Does the stiffness get greater or less when you are up and moving about?" Conclude with some such phrase as (23) "When you move quickly you get a sharp stabbing pain. Can you do as much as anybody else if you go slow?"
The last question is a valuable one for testing the patient's mental outlook. It puts him on his mettle. A genuine case answer's in the affirmative or with a negative that is obviously reluctant. Cases in which there is unwillinguess of the spirit as well as weakness of the flesh are not ashamed to give a negative the tone of which is whining in "war-wor'n" cases, and impressive, indignant, or sanctimonious in patients who are lnowingly exag. gerating their symptoms.

If the answers seem to coincide with the definition of myalgia given above, the diagnosis is made and a note registered for future reference as to the degree of the condition, and as to the degree, if any, of exaggeration employed.

\section{TREA'TMENT OF THROMBOSIS.}

\section{H. FAIRLEY MaRRIS, Captain R.A.M.C.}

Venous THRombosis such as occurs in the typhoid group of fevers may be speedily aborted by the intravenous injection of sodium citrate.

During the past two years seventeen cases of venous thrombosis have been under my care, the majority having arisen during the course of an infection bacteriologically proven to be by a momber of the enteric group, the remainder occurring during the course of other fevers of obscure origin.

This complication has long bcen recognized as prolouging convalescence and leading to permanent mischief such as troublesome swollen limb or the formation of intractable varix.

The signs and symptoms as seen in my series may be briefly described. liigors were noted in four of the cases. Fever was always present; pain invariably so, on two occasions being so severe that the question of intestinal perforation arose. Swelling of the limb was always present, usually appearing on the third day from onset of the other symptoms. In most of the cases the thrombus conld be felt.

Among the enteric cases the distribution was as follows: Left femoral 9, right femoral 1, right and left femorals 1 , left iliac 2, right and left iliacs 1 .

The remain ing three cases occurring during the course of other fevers were: Lef t femoral 2, right and left pop. liteals 1 .

The earlier cas es were treated on the

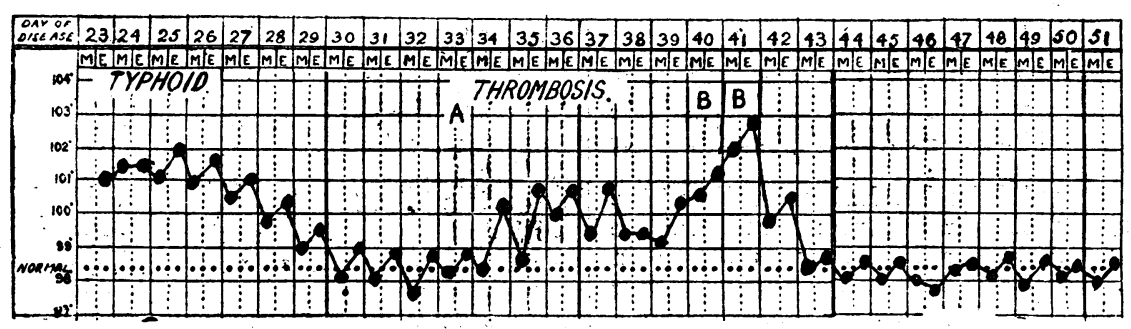

CASE 1.-A = Pain in left iliac fossa. $B=$ Injection of 0.5 per cent. sodium citrate. A speedy recovery took place. measurements taken on the days stated: solution warmed and sterilized was slowly ruu into the median basilic vein of the left arm. Twelve hours later the pain had almost gone. The following day a second injection of $8 \mathrm{oz}$. was given, and by the next morving the temperature had fallen, the patient was free from pain, and the abdomen was quite soft.

Imperial drink was given before the first injection; thereafter this was suspended. Below are shown $a$ few of the calf

\begin{tabular}{|c|c|c|c|c|c|c|c|c|}
\hline \multicolumn{7}{|c|}{ Day' of Disease. } & Right Calf. & Left Calf. \\
\hline 34 th & $\infty$ & $\omega$ & $\infty$ & $\cdots$ & $\ldots$ & ... & $10 \frac{1}{2}$ in. & $10 \frac{1}{2} \mathrm{in}$. \\
\hline 35th & $\cdots$ & $\cdots$ & $m$ & $\mu$ & $\approx 0$ & $\cdots$ & 102, & $12 \frac{1}{2}$ \\
\hline 37 th & $\infty$ & .. & ... & $\ldots$ & $\ldots$ & œ. & 121. & $122^{3} \ldots$ \\
\hline 40th & $m$ & cos & ". & $\cdots$ & $\ldots$ & $\ldots$ & $13 \frac{1}{2}=$ & $133 \ldots$ \\
\hline 45th & $\ldots$ & ... & ... & a.. & $\cdots$ & ... & $121 "$ & $123 "$ \\
\hline 57 th & $\ldots$ & $\ldots$ & .. & ... & $\infty$ & o.. & 110 & $11 "$ \\
\hline 60th. & Got & ip fo & firs & ime & & & & \\
\hline 61st & • • & ... & ... & ... & ... & ... & 109 " & $10^{3}$ \\
\hline 73ra. & Noo & den & $\ldots$ & $\ldots$ & $\ldots$ & ... & $10 \frac{3}{4}$ & $10^{3}$ \\
\hline 74th. & Eva & uat & as & ralk & $\mathrm{ggc}$ & & & \\
\hline
\end{tabular}
From information received it was learnt that this patient
was returned to duty 104 days from the onset of his illness-. that is, seventyfour days from the beginning of the thrombosis:!

This result was so striking when compared with those cases I had already seen that I decided in future to treat such cases by the oral and intravenous

usual lines-namely, locally with anodyne liniments, and internally by the liberal administration of citric acid and a milk-free diet.

The following is the first case treated by the intravenous iniection of sodium citrate:

I soldier (Case 1 in the table), aged 19, admitted to hospital the twenty-third day of his illness, which was subsequently 2. The temperature was $101^{\circ} \mathrm{F}$., and tre pulse 106 per minute. By the thirty-second day the temtre pulse 106 per minute. By the thirty-second day the tem ersture had regained the normal by

On the thirty-fourth day the temperature rose to $100^{\circ}$ F., and r.A patient complained of considerable pain in the lower par $r^{i}$ the left ablomen. A thrombus was suspected, but nothing ould be felt, and measurements round the two lower limbs a ine calves gave the same result-namely, 101 in.

isy the thirty-fifth day the left leg was swollen, and on the Whirty-seventh day oedema was observed in the right ankle. Wnth day the man was in such agony and the abdomen so :1gid that the possibility of an intestinal perforation was onsidered.

By the fortieth day the thighs resembled bolsters, and the superficial veins on the lower part of the abdomen became so conspicuous that the inferior vena cara appeared to be involved.

I thereupon resolved to try the effect of a 0.5 per cent. solution of sodium citrate in normal saline. Half a pint of this methods alternately. Limb measurements were taken daily. On two occasions an attempt was made to compare the coagulation time of the blood before and after. the injections.

The method used was as follows: a long capillary tube was drawn out and filled with the patient's blood from a finger prick; the tube was then quickly broken into incllong pieces. Every quarter of a minute one of these was taken and the blood expelled by blowing, until, on account of coagulation, this was no longer possible. In Case No. 4 it was found that the blood could be expelled from only eight of the tubes before the injection, whereas after the injection the blood was readily expelled from twenty-four tubes. The coagulation time of the blood had been changed from two to six minutes.

In the earlier cases the injections were followed by rigors occasionally, which occurred as early as half an hour and as late as three hours afterwards; they were never severe, and were quickly relieved by half an ounce of brandy and hot bottles. IVith more careful preparation of the citrate solution, using recently distilled water and eflicient sterilization, the rigor's have not been observed. Rigor's are not.infrequently observed after intravenous injections of other substances, and this is not an important point.
The fullowing table safficiently explains itself. 
Conclusions.

From the above series of cases it would appear justifi. able to conclude that the treatment of thrombosis by this method does quickly arrest the process. From the patient's point of view the almost immediate release from pain was most gratifying.

The comparison of a series of cases is always a difficult niatter. 'To obviate this difficulty cases were treated alternately by the two methods, and so may be considered unselected. In renlity the cases treated by the intravenous method rvere, on the whole, the more serious.

Analysis of the tro groups shows that in those treated by the intravenous method the subsequent period of pyrexia was shorter by an average of four days and tire onset of convalescence by an average of ten days than in those cases treated by the oral method.

Reference to the table also shows that the average number of days from the onset of thrombosis to evacuation ini the cases treat.d by the iutravenous method was thirty days, while in those cases treated by the oral method it was thirty-nine. It will, moreover, be noted that, whereas in the series of seven cases treated by the intravenous method five were evacuated as walking and two as sitting cases, and in one only was there oedema present on dis charge; in the oral series of ten cases, only five were cvacuated as walking and three as sitting cases, while two had to be sent to England as stretcher cases, and in no fewer than five cases there was a considerable amount of oedema present on discharge.

The known facts concerning the action of citrates on the blood as worked out by Sir Almroth Wright would lead one to expect that it would lengthen the coagulation time, and in my own series this is confirmed by the experiments in the coagulation time before and after the arlministration of sodium citrate in the course of treatment recorded above.

Moreover, not only is the coagulation time increased, but the tendency of the blood to coagulate is diminished. This, as is commonly known, cau be demonstrated in vitro. With the application of citrate to the blood in circulation, in which as in the case of thrombosis a clot has formed, the formation of further clot is apparently prevented, and such clot as is already formed would then seem to behave in the same way as a clot may be seen to behave outside the body-that is to say, it rapidly shrinks, with the expression of serum, and so opens up the venous channels.

The circulation is then speedily restorch, the clot being ultimately absorbed. 'The better' results obtained by the administration of the citrate intravencusly than orally would seem to be depenient upon the more immediate and intimate manner in which the drug is brought into relation with the blood by the former than by the latter method.

\section{Ifitures}

os

TIIE ANATOMICAL AND PHYSIOLOGICAT PRINCIPLES UNDERLYING THE TRE.ITMENT OF INJURIES 'TO MUSCLES, BONES, AND JOINTS.

Given at the Royal college of Strgeoss of Exulixo, Noveyber-Deceuber, 1917.

BY

Professor ARTHCR KEITH, M.D., F.R.S., CONSERVATOR OF TID MCSEY II.

\section{THE PRINCIPLES AND PRAC'TICE OF} HUGH OWEN THOMAS.

Mes could not have approached a common ohjective by more diverse rontes than did Hunter and Hilton on the one hand and H. O. Thomas on the other. Hunter aud Hilton worked long and hard in the dissecting and post-mortem rooms in the search of facts to guide them in formulating rational means of treatnent; they observed the efticacy of their methods in regulated hospital wards and on closely tended private patients. The circumstances anidst which Thomas matured his experience were very different: his field of obserration was the steady stream of accident cases drawn, from the dockland of Livernool, which passed throagh his surgery; his field o' experiment lay in his workroom, where, in workman's attire, and with the hand of an expert, he wrought the exact form of splint or machine which he desired for: the treatment of each particular case that came under his cale. Here, then, is a surgeon of a new kind, one who could and did use his lnuife, but it was his final and fixed opinion, founded on thirty-three year's crowded with experiments on orthopaedic cases, that the blacksmith's hannmer, deftly used, was, in most cases, a more powerful reparative insurument than the surgeon's knife.

'Ihomas was born and bred an orthopaedic surgeon. His father, Evan 'Thomas, had his home and surgery, so Professor Rushton Parker has informed me, at 72, Great Crosshali Street, Liverpool, where, although unqualified, he was the referee of certain workmen's clubs-dock gatesmen, ship's carpenters, boilermalsers, and several others. He had tive sons: Hugh Owen was the eldest; two others besides him-Ricliard and Evan-studied and qualified in medicine; as the boys grew up they had to help in the surgery and could not fail to gain a first-hand knowledge of injury and disease. Indeed, it was proposed at one time that Hugh should become his father's apprentice, but the ill state of his health-lie never at any period of his life was robust-led to a change of plan. In 1851, at the age of 17, he was apprenticed to his maternal uncle, Dr. Uwen Roberts of St. Asaph. In 1855, at the age of 21 , he went to Edinbargh to study medicine. Syme and Spence and Simpson were in the heyday of their fame; Goodsir was teaching anatomy; there was then a demonstrator of anatomy newly arrived from Loudon-William 'Turner. Lister was also there commencing the Edinburgh phase of his great career. But in Thomas's writings there is never an allusion to his life in Edinburgh ; only one man seems to have impressed him there, Hughes Bennett. He apparently spent little more than a year in Edinburgh, for in 1857 he was studying at University College, London; of his life and experience in London he never gives us the slightest hint. In 1857, in his 23rd year, he became a Member of this College, and in the following year, still in poor health, he returned to Liverpool, where he spent the thirty-three years of his professional life amongst the accident cases of Liverpool dockland. He began in easy circumstances so far as finance was concerned. Professor Rushton Parker informs me that le had at first a very hard struggle, but ultimately acquired the surgeonships of the variuus clubs which had been held by his father, and that thus an aunual incoine of at least $£ 500$ was assured him. His cases supplied him with all his interests - his cases and his workroom where ho designed, moditied, and perfected the methods he applied for treat ment. He lnew and sympathized with the working people; there were many poor and ailing men round him who could ill afford to leave their work and seek triatment on week-days; Thomas established a Sundily clinic for them-he eased his poor patients and enriched his own store of linowledge.

Thus he lived from his twenty.fourth to his fortieth years, his fame during that period being still confined to dockland. In 1874 an event occurred which led to his labours becoming better known. Mr. Parker, police surgeon, had reason to visit Mr. Thomas, who then had his surgery and hospital in Greta Street, in connexion with a case-that of an inspector of police-who was then under Mr. Thomas's care on account of a compound fracture of the leg. Mr. Parker had taken with him his son, Rushton, a young surgeon of 28 , with an assured future in the Liverpool School of Hedicine. We can learn the effect of that visit from the preface which Thomas wrote for his first important publication on Diseases of the Hip, Knee, and Ankle Joints, with their Deformities: Treated by a New and Efficient Method (London: H. K. Lewis. First edition 1875; third edition 1878). It was not actually his first publication, for in 1873 he described a method of using silver wire ligatures for the treatment of componnd fractures of the mandible. The ligatures were fixed by a terminal spiral which could bo conveniently tightened as the maudibular fragments yielded. He also advocated then a practice adopted in the present war, of removing any tooth situated on the line of fracture, as its presence there always retarded union. Once started as a writer he continued to issue Contributions to Surgery and Medicine almost annually until death brought an end to a laborious career, handicapped by indifferent health. He died in 1891 at the age of 57. Even in the manner of publication he emphasized his individuality. His writings 